\title{
Analyses of Horse Tack from the Carpathian Basin Dating to the Late Antiquity and the Early Migration Period
}

\author{
Réka Ágnes Piros* \\ Department of Archaeology, University of Szeged, Hungary \\ *Corresponding author: Réka Ágnes Piros Faculty of Arts Department of Archaeology, University of Szeged, Hungary
}

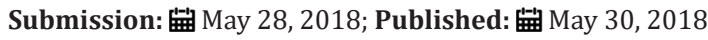

\section{Introduction}

The use of Archaeometrical methods in archaeological research are spreading because of their accuracy and the achievable new results. Regarding that the analyzed finds were restored in the 20th century, the determination of their material composition could be misinterpreted (e.g. define copper as bronze) [1]. Because of the valuable worth of these metal horse harnesses it was essential to use a non-destructive method for the analysis. With the help of any $\mathrm{X}$-Ray Fluorescence (XRF) instrument this issue can be resolved [2]. Fortunately, the investigation of the analogies of the Carpathian Basin originating trappings began. Therefore, we can examine them in context [3]. The other approximation is from the view of archaeology, considering the typology, the decoration and the material.

The analysis and the periodization of horse trappings dated to the Late Antiquity and Early Migration Period were usually performed in the publication of the excavated site. These days it is more accurate to examine them in context and with the help of their analogies. Finding these could help the determination of the potential provenance and the various impacts, which affected the manufacturing and the decorating of these objects. At the same time, we have to consider that some of them laid in graves [4] while others in so-called funerary offerings [5]. The finds from the studied period can mostly be connected to the Eurasian equestrian steppe nomads. Earlier the researcher called them 'Hun' but regarding the various people within the Hunnic army they should be termed Hun Age objects because we cannot be sure of the ethnical affiliation of the owner [6].

These assemblages can include the following objects: parts of the bridle (bit, mounts, buckles, strap ends), parts of the saddle (mounts, buckles) and other objects linked to horses [7]. The bits are either circular or bar-shaped, which became the dominant type of the military material in the Hun Age [8]. They can be decorated with a pressed, gilded silver plaque [9]. The material of the mounts were mostly copper or silver, ornamented with gilded silver plaque, gold plaque [10] or in the case of a silver sheet with fire gilding
[11]. The shape of the pendants could be various, but there are some recurring forms: axe, disc, square, leaf, cicada and crescent. There is also one, undoubtedly Hunnic mount type: the D-shaped saddle plaque [12]. It was decorated with punched dots designed to form fish scales according to earlier interpretation but presumably, they picture the feathers of a bird of prey, maybe of an eagle. Almost every mount (bridle and saddle) has a punched, stamped or pressed ornamentation. In the course of the research it attracted our attention that the pendants, which were manufactured in pairs or in multiple pieces, do not have the same punched/stamped/ pressed motif. We discovered small differences, for example one of the axe-shaped pendants from Untersiebenbrunn is finer in contrast to the other, which has some mistakes (e.g. carved lines to punch in a straight line, varied number of punched motifs).

A potential conclusion would be that the goldsmith master worked together with his apprentice in the workshop. The form was more significant than the motifs of the ornamentation, so maybe he decorated the first object and then he let his apprentice ornate the other one. The goldsmith punched or pressed different patterns, such as grape, wolf's tooth, petal, dot, circle, lines, square and triangle. With the great Hunnic army appeared a new ornamentation technique on these type of objects in the 5th century, the inlay of gemstones. The typology of the horse tack results in two main chronological group: Early Hun Period and Late Hun Period (Age of Attila) [13].

According to the analysis of the type of the ornamentation we can define which ethnic group made impact on the manufacturing. The most effect was made by the Bosporan Kingdom, the Roman Antiquity, the central Asian and the Eurasian steppe, as well as the German and Sarmati an tribes. The newest researches demonstrate that we must rethink some previous statements: e.g. Sösdala-style spread from the north to the south but as it seems, the opposite direction is more likely [14]. Most of the investigated assemblages presumably arrived with Eastern people fleeing the Huns or with the Hun army, but the possibility cannot be ruled out that an Eastern descanted goldsmith merged his acquired knowledge with 
the newly effects (Roman Antiquity, German). It is not yet clear whether the artisan or the technology reached the Carparthian Basin first.

For the elemental analyses we used once a Bruker's Tracer and in the other cases a Spectro Xsort Combi. Both enables the user can immediately evaluation (in \%) and the processing of data on a PC An advantage is as well that the handheld XRF can be useful at the excavation, if the situation requires it. The measuring only takes 90 seconds. It is recommended to discuss the results with someone who is well versed in archaeometry.

Every measured base sheet that was referred to as bronze is in fact copper $(\mathrm{Cu})$ without any alloying elements. According to this information, it would be suggested to re-examine the assemblages found and inventoried in the 19th and early 20th century to exclude possible misconceptions. Other small quantity elements, such as nickel (Ni) may refer to the provenance of copper. We already know that this kind of copper is not available in the mines of the Carpathian Basin, consequently these artifacts were produced beyond. For a more precise determination of the production, it is necessary to create a database of the mined copper of the affected areas (Europe and Eurasia) and to enquire the elemental composition of these analogies.

Few say that during the restoration the analyzed surface was corrupted because of applied chemical materials, which appears in the measured data. Luckily, this is just a misapprehension. The XRF investigation of four Carpathian Basin originated assemblages is already done. The only issue in the data was caused by the applied modern plaque that was used to protect the thin gold foil of Léva. Thoughtfully, the conservator left some fragments without such plaques. The preliminary results show that in the near future this type of investigation will be inevitably. With the support of XRF the science of archaeology will widen, opening a new perspective and new possibilities.

\section{References}

1. Piros Réka Á (2018) Analysis of a gilded silver sheeted bridle from Hungary-preliminary results. STAR: Science \& Technology of Archaeological Research
2. Scott RB (2016) A Methodology for qualitative arcaeometallurgical fieldwork using a handheld $x$-ray fluorescence spectrometer. STAR: Science \& Technology of Archaeological Research 1(2): 70-80.

3. Dal Lovisa (2017) Scientific analyses of Sösdala objects. In: Fabech Ch, Näsman U (Eds.), The Sösdala horsemen and the equestrian elite of the fifth century Europe, pp. 131-151.

4. Kubitschek W (1911) Grabfunde in Untersiebenbrunn (auf dem Marchfeld). Jahrbuch für Altertumskunde 5: 32-74.

5. Tomka P (1986) Die eigenartige Variante der Begrabungsgewohnheiten von den Steppen. Arrabona 22(23): 5-34.

6. Tejral J (2010) Slovenskáarcheológia 58(1): 81-122.

7. Piros RÁ (2015) Day or night they spent on horseback-Or the investigation of the early Migration Period horse harnesses on the basis of the eastern finds. In: Balogh Cs, Major B (Ed.), Hadakútján XXIV Conference of Young Scholars on the Migration Period Esztergom, pp. 447-468.

8. Ahmedov Ilia R (2001) New data about the origin of some constructive parts of the horse-harness of the Great Migration Period. In: Museum $\mathrm{AD}$ (Ed.), International Connections of the Barbarians of the Carpathian Basin in the $1^{\text {st }}-5^{\text {th }}$ century pp. $363-388$.

9. Piros Réka Á (2016) The bridgehead from Hungary in the Berlin Museum of Pre- and Protohistory. Acta Praehistorica et Archaeologica 48: 109-119.

10. Istvánovits, Eszter, Kulcsár, Valéria (2014) New find of hun age saddle plates from north-east hungary. In: Cociș S, Ursuțiu A (edn), Gedenkenschrift zum hundertsten Geburtstag von Kurt Horedt, pp. 269278.

11. Anheuser Kilian (1999) Im Feuer vergoldet-Geschichte und Technik der Feuervergoldung und der Amalgam-versilberung, Stuttgart, Germany.

12.Zaseckaja, Irina P (1994) Culture of the nomads of the South Russian steppes in the Hunnic era (late IV-V centuries). [Nomadic culture of the South Russian Steppelands: the end of the fourth and the fifth centuries A. D.], St Petersburg, Russia.

13. Piros Réka Á (2015) Harnesses in the Late Antiquity and Early Migration Period in the Carpathian Basin. Actaluvenum Sectio Archaeologica Tomus 2: 87-109.

14. Fabech, Charlotte Näsman, Ulf (2017) Sösdala interpreted in its glocal context. In: Fabech Ch, Näsman U (Eds.), The Sösdala horsemen and the equestrian elite of the fifth century, Europe, pp. 329-349.
Creative Commons Attribution 4.0 International License

For possible submissions Click Here

\section{Submit Article}

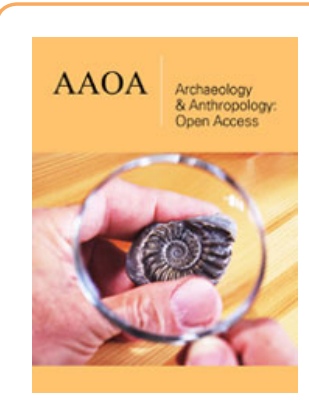

\section{Archaeology \& Anthropology: Open Access}

\section{Benefits of Publishing with us}

- High-level peer review and editorial services

- Freely accessible online immediately upon publication

- Authors retain the copyright to their work

- Licensing it under a Creative Commons license

- Visibility through different online platforms 